\title{
FUNGSI DAN PERAN ASPAPI \\ DALAM MENUNJANG PENDIDIKAN \\ BIDANG ADMINISTRASI PERKANTORAN
}

\author{
Oleh Muhyadi
}

muhyadi@uny.ac.id

\begin{abstract}
Abstrak
Administrasi perkantoran merupakan salah satu bidang yang memegang peran strategis dalam organisasi modern. Keberhasilan organisasi mencapai tujuan yang sudah ditetapkan, banyak ditentukan oleh kualitas keputusan yang diambil pimpinan, sementara itu kualitas keputusan banyak ditentukan oleh ketersediaan dan keakuratan informasi yang diperlukan dalam rangka pengambilan keputusan tersebut. Pekerjaan bidang administrasi perkantoran adalah bidang yang menyiapkan informasi yang diperlukan oleh organisasi, utamanya pimpinan. Oleh karena itu pengelolaan administrasi perkantoran mutlak harus dilakukan secara profesional. Guna mencapai kondisi yang diharapkan tersebut diperlukan persiapan yang cukup berupa pendidikan administrasi perkantoran yang berkualitas dan pembinaan yang dilakukan secara terus menerus terhadap mereka yang sudah bekerja dalam bidang ini. Untuk itulah diperlukan wadah yang mampu mengembangkan profesi administrasi perkantoran, sekaligus melindungi kepentingan pelanggan dari layanan yang tidak berkualitas. Atas dasar pemikiran seperti itulah maka kemudian dibentuk asosiasi profesi yang mewadahi pakar, praktisi, dan pemerhati bidang administrasi perkantoran, yang diberi nama ASPAPI (Asosiasi Sarjana dan Praktisi Administrasi Perkantoran Indonesia). Keberadaan ASPAPI diharapkan mampu memberikan sumbangan yang berarti bagi pengembangan bidang administrasi perkantoran, baik pada level pendidikan maupun praksis.
\end{abstract}

\section{Pengantar}

Penerapan berbagai temuan teknologi informasi, komunikasi, dan transportasi akhir-akhir ini, berdampak luar biasa pada hampir seluruh segi kehidupan manusia, termasuk jenis dan kualitas pekerjaan yang dilakukan masyarakat. Gaya hidup manusia saat ini tak terbayangkan pada dua puluh atau bahkan sepuluh tahun yang lalu. Siapa sangka kalau dewasa ini sebagian (besar) murid-murid sekolah dasar dan menengah, apalagi mahasiswa, selalu menenteng handphone kemanapun mereka pergi. Siapa sangka setiap orang kini dapat mengakses berbagai macam informasi dari seluruh penjuru dunia dengan sangat mudah dan sangat murah. Tidak terbayangkan 
pula bagaimana suasana setiap bandara saat ini begitu padat oleh calon penumpang pesawat, lebih padat dari calon penumpang bis di terminal atau calon penumpang kereta api di stasiun.

Perubahan yang signifikan tersebut juga terjadi pada bidang administrasi, utamanya pada pola pengelolaan informasi, baik jenis, penggunaan, maupun perlakuan terhadap bahan informasi. Di berbagai negara maju, pengelolaan informasi yang didukung teknologi maju menjadikan proses kerjasama semakin efisien, informasi semakin tertata, dan kinerja organisasi semakin meningkat. Tetapi yang terjadi di Indonesia belum seperti yang digambarkan tersebut. Bahkan praktik administrasi di berbagai lembaga (terutama lembaga pemerintahan) akhir-akhir ini menunjukkan kondisi yang sangat memprihatinkan. Berita tentang kejahatan administrasi, perilaku para penyelenggara organisasi (negara) yang korup, pejabat yang menyimpang dari aturan yang ada, terjadi dimana-mana. Berbagai praktik kotor tersebut merambah ke hampir semua sektor kehidupan dan semua level organisasi, seolah tidak ada ujung pangkalnya, sehingga orang tidak tahu lagi dari mana harus mulai membenahinya. Sungguh kondisi yang sangat menyedihkan.

Pada sisi yang lain, kita juga harus mengakui bahwa diantara negara-negara lain, bahkan di kawasan Asia Tenggara, Indonesia tergolong negara yang 'tertinggal'. Padahal Indonesia memiliki berbagai sumber daya melimpah (baik sumber daya alam maupun sumber daya manusia), yang sangat potensial dikembangkan sebagai modal pembangunan sehingga sangat mungkin menjadikan Indonesia setara bahkan leading diantara negara-negara di kawasan Asia Tenggara. Sayang sekali berbagai kelebihan yang dimiliki tersebut belum dapat dimanfaatkan secara optimal. Salah satu kunci untuk menuju ke arah Indonesia yang lebih baik ialah melalui pendidikan, khususnya pendidikan kejuruan. Mengapa demikian? Karena sebenarnya Indonesia memerlukan tenaga terampil tingkat menengah dalam jumlah yang sangat besar, yang hanya dapat dipenuhi lewat pendidikan kejuruan. Apalagi ke depan tenaga kerja Indonesia juga harus mampu bersaing dengan tenaga kerja asing yang tentu saja memiliki tingkat keterampilan yang cukup tinggi. Diantara sekian banyak bidang kejuruan yang harus mendapatkan perhatian adalah kejuruan bidang administrasi perkantoran.

Sebagai komunitas yang peduli dengan masalah administrasi, kita merasa terpanggil untuk berupaya mencari solusi, setidaknya memberikan kontribusi yang diharapkan mampu mengurangi persoalan yang membelit bangsa ini, khususnya dalam upaya meningkatkan kompetensi sumber daya manusia bidang administrasi perkantoran.

\section{Pandangan Masyarakat terhadap Administrasi Perkantoran}

Administrasi perkantoran merupakan bagian yang sangat penting dari setiap proses kerjasama yang berlangsung dalam sebuah organisasi. Setiap organisasi harus didukung oleh kegiatan administrasi perkantoran yang dikelola secara profesional. Selama ini orang lebih sering 
mengenal pekerjaan perkantoran sebagai pekerjaan tatausaha. Meskipun penyamaan pengertian ini tidak terlalu salah tetapi orang sering memandang keliru terhadap peran pekerjaan ketatausahaan. Pada umumnya orang menganggap tatausaha adalah pekerjaan yang kurang penting dan karenanya dapat dilakukan oleh siapa saja tanpa harus memiliki keterampilan khusus yang diperoleh melalui proses pendidikan yang lama. Pendapat seperti itu sangat merugikan bidang perkantoran, baik dalam posisinya sebagai kegiatan praksis pendukung proses kerjasama maupun dalam konteks pengembangan ilmu. Di samping pandangan yang keliru terhadap peran administrasi perkantoran tersebut, orang kadang-kadang juga menyamakan administrasi perkantoran dengan sekretaris. Akibatnya, kompetensi sekretari diidentikkan dengan kompetensi administrasi perkantoran. Padahal kesekretarisan hanyalah bagian dari kegiatan administrasi perkantoran.

Pendapat yang kurang tepat tersebut perlu diluruskan agar profesi administrasi perkantoran dapat dikembangkan secara proporsional. Sebagai bidang kerja yang mengelola informasi, administrasi perkantoran menempati posisi strategis dalam setiap organisasi. Kenyataan yang ada menunjukkan bahwa posisi informasi sangat vital dalam mendukung keberhasilan organisasi. Tampaknya kini orang mulai menyadari betapa pentingnya peran informasi bagi pengambilan keputusan organisasi. Kenyataan ini kemudian mengubah cara pandang orang terhadap informasi termasuk segala sesuatu yang terkait dengan pengelolaan informasi. Wajah kantor -tempat dimana informasi dikelola- kini tidak lagi terkesan kumuh dengan tumpukan berkas-berkas arsip yang berdebu dan karyawan yang lusuh. Selain lebih tertata rapi, posisi kantor lebih 'bermatabat', dengan kondisi fisik yang jauh lebih baik dan kinerja SDM yang jauh lebih efisien. Yang lebih penting dari itu semua, posisi kantor sebagai pusat informasi menjadi semakin strategis dalam menjamin kelangsungan hidup dan bahkan mengembangkan organisasi, apapun bentuk organisasi yang bersangkutan. Oleh karena itu pekerjaan kantor harus dikelola secara profesional.

Efisiensi pekerjaan kantor juga menjadi tanggung jawab pimpinan. Selain harus menyediakan berbagai sarana dan prasarana yang diperlukan, pimpinan juga bertanggung jawab untuk mengembangkan kemampuan dan kompetensi SDM yang menangani pekerjaan kantor. $\mathrm{Hal}$ ini mudah dipahami karena fungsi pekerjaan kantor dalam sebuah organisasi berperan sangat strategis dalam menunjang pencapaian tujuan organisasi yang bersangkutan. Pekerjaan kantor adalah sebuah profesi yang harus dikembangkan secara terus menerus mengikuti perkembangan dan tuntutan dunia kerja.

Seiring dengan perkembangan ipteks, masyarakat kini menuntut diperolehnya produk dan layanan jasa yang lebih berkualitas dalam berbagai bidang, termasuk layanan pekerjaan kantor. Produk dan layanan kantor yang berkualitas hanya dapat dihasilkan oleh sumber daya manusia 
yang berkualitas pula. Potensi yang ada pada SDM harus dimanfaatkan dan dikembangkan secara optimal. Namun harus disadari bahwa pada kenyataannnya, manusia adalah faktor yang paling sulit diprediksi dan dikendalikan. Oleh karenanya faktor manusia harus dikelola dalam suatu organisasi yang memungkinkan anggotanya berkomunikasi satu sama lain dan berkembang sesuai potensi yang dimiliki. Asosiasi profesi merupakan salah satu wahana yang mampu mengakomodasi tuntutan semacam itu. Asosiasi profesi merupakan jaminan diperolehnya profesionalisme yang selalu berkembang.

\section{Profesi Bidang Administrasi Perkantoran}

Sebuah profesi dapat berfungsi secara optimal apabila dikembangkan secara terusmenerus. Untuk itu setiap profesi memerlukan wadah yang memungkinkan terjadinya interaksi antar pelaku dan terjadinya proses pengembangan secara terprogram. Dengan kata lain, diperlukan organisasi profesi yang mewadahi orang-orang yang peduli terhadap profesi yang bersangkutan.

Organisasi profesi (sebagaimana selama ini dipahami oleh masyarakat luas) adalah organisasi yang bersifat nirlaba, bertujuan untuk melindungi kepentingan anggota dan kepentingan publik pengguna profesi yang bersangkutan. Organisasi profesi umumnya menerapkan etika profesi dan standar pelatihan profesi dalam rangka melindungi kepentingan publik. Sejumlah organisasi profesi juga menerapkan sertifikasi profesional (sebagai bukti bahwa seseorang memiliki kualifikasi pada bidang tertentu) untuk dapat bergabung ke dalam profesi yang bersangkutan. Konsep seperti itulah yang digunakan sebagai pijakan pembentukan organisasi profesi bidang administrasi perkantoran di Indonesia yang selanjutnya disebut Asosiasi Sarjana dan Praktisi Administrasi Perkantoran Indonesia (ASPAPI).

Agak berbeda dengan profesi lain yang umumnya hanya berkepentingan dengan satu bidang tertentu, administrasi perkantoran merupakan profesi yang istimewa karena ia masuk ke dalam hampir semua bidang kegiatan manusia: bisnis, politik, pendidikan, militer, sosial, dan lainlain. Berbagai bidang tersebut berkepentingan dengan administrasi perkantoran karena cakupan administrasi perkantoran memang meliputi berbagai aktivitas harian yang dilaksanakan oleh setiap organisasi, antara lain berupa: perencanaan keuangan (financial planning), pencatatan berkas (recordkeeping), pengelolaan SDM (personnel management), perencanaan tugas untuk staf, pengawasan, dan pemeliharaan sarana prasarana yang diperlukan organisasi. Tanpa dukungan pengelolaan administrasi kantor yang profesional, mustahil bidang-bidang kegiatan sebagaimana disebutkan di atas berhasil mencapai tujuan yang diinginkan.

Di samping masuk ke berbagai bidang kerja, profesi administrasi perkantoran juga sangat dekat dengan posisi kepemimpinan karena setiap keputusan pemimpin memerlukan informasi akurat, cepat, dan tepat, yang hanya dapat disediakan oleh unit pengelola informasi yang 
merupakan kegiatan utama dari profesi administrasi perkantoran. Posisi seperti itu menjadikan administrasi perkantoran sebagai profesi yang sangat penting karena berkontribusi besar dalam menentukan maju-mundurnya organisasi. Dengan demikian tidak berlebihan jika profesi administrasi perkantoran seharusnya mendapatkan prioritas utama dalam pengembangan setiap organisasi. Kompetensi SDM pengelola administrasi perkantoran harus senantiasa dikembangkan dan perangkat kerja yang digunakan harus senantiasa diupdate dari waktu ke waktu. Ide pengembangan SDM bidang perkantoran seharusnya juga datang dari manajemen dimana mereka bekerja di samping dari anggota sendiri. Dengan demikian keberadaan asosiasi profesi bidang administrasi perkantoran, yang dikenal dengan nama ASPAPI (Asosiasi Sarjana dan Praktisi Administrasi Perkantoran Indonesia) seharusnya dipandang sebagai partner yang fungsional bagi pimpinan dalam meningkatkan kinerja organisasi.

\section{Peran ASPAPI dalam Pengembangan Bidang Administrasi Perkantoran}

Keberadaan ASPAPI diharapkan mampu memberikan kontribusi positif baik secara internal maupun eksternal terhadap pengembangan bidang administrasi perkantoran. Secara internal organisasi, ASPAPI diharapkan berperan dalam: (1) meningkatkan kemampuan dan kompetensi anggota yang pada gilirannya mampu meningkatkan kinerja dan jenjang karir anggota, (2) melindungi anggota dari ketidakpastian hukum dan masa depan, dan (3) meningkatkan kesejahteraan anggota. Sementara itu, secara eksternal keberadaan dan berfungsinya ASPAPI dengan baik diharapkan mampu: (1) meningkatkan kualitas produk dan layanan organisasi tempat anggota bekerja, (2) meningkatkan efisiensi dan produktivitas organisasi tempat anggota bekerja, (3) meningkatkan kesehatan organisasi, dan (4) melindungi konsumen dari produk dan layanan yang tidak berkualitas, dan (5) mengembangkan kajian ilmiah bidang administrasi melalui berbagai seminar dan aktivitas ilmiah yang lain, yang pada akhirnya mampu memberikan kontribusi bagi pengembangan ilmu administrasi ke depan.

Di samping kedua hal tersebut, ASPAPI juga sangat potensial berperan aktif dalam meningkatkan kualitas pendidikan kejuruan di Indonesia, utamanya bidang administrasi perkantoran. ASPAPI dapat mengambil posisi sebagai partner lembaga pendidikan formal dalam menyusun kurikulum pendidikan sehingga relevan dengan kebutuhan dunia kerja. Secara proaktif ASPAPI juga dapat berinisiatif menyelenggarakan berbagai pelatihan bidang administrasi perkantoran yang dapat diikuti oleh siswa SMK, guru, maupun mereka yang sudah bekerja pada bidang perkantoran. Dengan kewenangan yang ada, ASPAPI juga berperan sebagai lembaga pasangan bagi dunia pendidikan kejuruan dalam melaksanakan uji kompetensi bidang administrasi perkantoran. Berbagai upaya tersebut diharapkan mampu meningkatkan kompetensi bidang administrasi perkantoran bagi siswa SMK maupun praktisi. ASPAPI juga harus mampu menjalin 
kerjasama dengan berbagai organisasi yang memiliki kepentingan dengan profesi administrasi perkantoran seperti Musyawarah Guru Mata Pelajaran (MGMP) Administrasi Perkantoran dan Badan Nasional Sertifikasi Profesi (BNSP). Dengan berbagai upaya tersebut, eksistensi ASPAPI akan semakin dirasakan pentingnya dan pada gilirannya akan mampu meningkatkan kualitas, kompetensi, kinerja, dan daya saing tenaga kerja bidang perkantoran termasuk organisasi di mana para praktisi perkantoran bekerja, bukan saja dalam skala lokal tetapi juga regional, bahkan global. Dengan dimilikinya kemampuan dan kompetensi yang memadai oleh tenaga kerja lokal, tidak ada alasan bagi tenaga kerja Indonesia untuk tersisih dari tenaga asing dalam kompetisi global. Bagaimanapun juga tenaga lokal memiliki sejumlah nilai lebih dibandingkan tenaga asing. Selain lebih memahami budaya Indonesia, tenaga lokal sebenarnya memiliki ketekunan dan keuletan bekerja yang tidak kalah dibandingkan tenaga kerja asing.

Bagi praktisi administrasi perkantoran sendiri hendaknya disadari bahwa pekerjaan kantor merupakan jenis pekerjaan yang memiliki dinamika tinggi seiring dengan perkembangan ipteks sehingga menuntut pelakunya untuk memiliki sikap terbuka serta dinamika dan kemauan berkembang yang tinggi pula. Praktisi administrasi perkantoran harus tanggap dan responsif terhadap perkembangan dan tuntutan lingkungan. Kepedulian terhadap perkembangan lingkungan hendaknya tidak saja dilakukan secara pasif tetapi lebih bersifat proaktif dalam mengenali dan mengidentifikasi perubahan yang terjadi agar dapat menyesuaikan bahkan mengantisipasinya dengan baik. Untuk mencapai kondisi seperti itu, ASPAPI harus mampu menyusun program kerja yang rasional, feasible, dan fungsional, antara lain berupa program-program pendidikan dan pelatihan yang mampu membekali anggota dalam mengakomodasi perkembangan yang terjadi."

Sebagai konsekuensi dari karakteristik pekerjaan kantor yang sangat dinamis tersebut, lembaga pendidikan penghasil tenaga kerja bidang administrasi perkantoran, baik pada level sekolah menengah maupun perguruan tinggi, juga harus selalu menyesuaikan diri dengan dinamika ipteks sehingga lulusannya mampu mengikuti perubahan yang terjadi. Kurikulum lembaga pendidikan harus senantiasa ditinjau ulang secara berkala untuk menyesuaikan dan mengantispasi perkembangan yang terjadi. Pemangku kepentingan hendaknya diposisikan sebagai partner utama dalam setiap upaya perubahan dan pengembangan kurikulum. Dalam konteks ini ASPAPI yang beranggotakan pakar, praktisi, dan pemerhati bidang administrasi perkantoran berperan sebagai partner yang mampu menyumbangkan pikiran serta informasi lapangan yang diperlukan bidang administrasi perkantoran. 


\section{Penutup}

Asosiasi Sarjana dan Praktisi Administrasi Perkantoran Indonesia (ASPAPI) merupakan organisasi profesi yang diharapkan mampu berperan dalam meningkatkan kualitas sumber daya manusia, baik yang sedang mempersiapkan diri maupun yang sudah menekuni bidang administrasi perkantoran. Peningkatan kualitas SDM akan meningkatkan daya saing dan nilai tawar mereka dalam kancah persaingan, tidak saja pada tingkat lokal tetapi juga global. Secara khusus, keberadaan dan berfungsinya ASPAPI dengan baik akan memberikan kontribusi yang signifikan dalam hal: peningkatan kompetensi dan kapasitas anggota baik dalam posisinya sebagai akademisi maupun praktisi; peningkatkan kinerja organisasi di mana anggota bekerja; peningkatan kepastian hukum dan kesejahteraan anggota; peningkatan kompetensi lulusan sekolah kejuruan melalui uji kompetensi; dan jaminan diperolehnya layanan berkualitas bagi masyarakat pengguna jasa administrasi perkantoran.

\section{Daftar Pustaka}

Buyung Ahmad Syafei, Kompeten dan Kompetensi (F:/Kompeten dan Kompetensi <thought's.htm> (diunduh: 29 September 2010)

Keeling, B. Lewis, Norman F. Kallaus, John J.W. Neuner. 1978. Administrative Office Management. Cincinnati: South-Western Publishing Co.

Muhyadi, 2005. Peran Pendidikan Administrasi dalam Peningkatan Daya Saing Bangsa. Pidato Pengukuhan Guru Besar UNY.

Sistem Administrasi Negara Kesatuan Republik Indonesia. 2003. Jakarta: Lembaga Administrasi Negara.

Standar Kompetensi Kerja Nasional Indonesia (SKKNI) Bidang Administrasi Perkantoran. 2007. Kepmenakertrans RI, Nomor: KEP.195/MEN/IV/2007.

F: ExecutiveOfficeAdmin.htm (diunduh: 29 September 2010).

(file:///F:/Office Administration.htm). (diunduh: 28 September 2010).

Wikipedia, The Free Encyclopedia, Office Administration. F:/Office_Administration.htm (diunduh: 26 September 2010) 